\title{
COMPRESSIVE AND TENSILE STRENGTH OF CONCRETE USING LATERITIC SAND AND LIME STONE FILLER AS FINE AGGREGATE
}

\author{
A.Jayaraman ${ }^{1}$, V.Senthilkumar ${ }^{2}$, M.Saravanan ${ }^{3}$ \\ ${ }^{1}$ Assistant Professor, Department of Civil Engineering Bannari Amman Institute of Technology, Sathamangalam-
} 638401, India

2 Assistant Professor (Sr. G), Department of Civil Engineering Bannari Amman Institute of Technology, Sathamangalam-638401, India

${ }^{3}$ Assistant Professor (Sr. G), Department of Civil Engineering Bannari Amman Institute of Technology, Sathamangalam-638401, India

\begin{abstract}
This paper is part of a study investigating the structural characteristics of concrete using various combinations of lateritic sand and lime stone filler as complete replacement for conventional river sand fine aggregate. The lime stone filler obtained from limestone quarries. The concrete are made using varying contents of lateritic and lime stone filler as fine aggregate. The quantity of laterite is varied from 0\% to 100\% against lime stone filler at intervals of 25\%. Samples of concrete (eg.cubes and cylinders) are made in three different grades, namely: M15, M20 and M25. It was found that 0.55 water/cement ratio produced higher compressive strengths, tensile strength and better workability for M20 mix, proportion. Specifically compressive and tensile strength ranged from $21.06-35.2 \mathrm{~N} / \mathrm{mm}^{2}$ and $10.06-15.5 \mathrm{~N} / \mathrm{mm}^{2}$ for the mixes considered. These results compare favourably with those of conventional concrete. The concrete was found to be suitable for use as structural members for buildings and related structures, where laterite content did not exceed $50 \%$.
\end{abstract}

Index Terms: compressive strength, lateritic sand, lime stone filler and tensile strength

\section{INTRODUCTION}

This paper is part of a study investigating the structural characteristics of concrete using various combinations of lateritic sand and lime stone filler as complete replacement for conventional river sand fine aggregate. Limestones are sedimentary rocks primarily of calcium carbonate. Limestones are generally obtained from the calcareous remains of marine or fresh water organisms embedded in calcareous mud. They change from the soft chalks to hard crystalline rocks. The use of limestone as a concrete aggregate has sometimes been suspect on account of the unsuitability of the poorer grade rocks, and also because of a widespread fallacy that limestone concrete is less resistant to the action of fire than concrete made from other aggregates. He suggested that the use of limestones might not be beneficial in concrete products, which are to be cured in high-pressure steam. For many years has been increasingly used in concrete as coarse aggregate, lime stone filler or as a main cement constituent. It is applied in high performance concrete as well as in normal or low performance concrete. Compared to plain concrete with the same w/c ratio and cement type, concrete with high limestone filler content with suitable particle size distribution possesses generally improved strength characteristics. Concrete made with limestone filler as partial replacement of natural sand in concrete can attain lime stone filler up to $20 \%$ without adversely effecting concrete strength [1]. Limestone filler is regularly used as mineral addition in self-compacting concrete. In this overview, some interesting results are summarized concerning hydration, microstructure development, transport properties, and durability [2]. Fly ash can develop some mechanical strength, due to slowly pozzolanic reaction, strength which grows after longer periods of time. The simultaneous presence of the limestone filler and fly ash in cement cumulates the effects determined by every addition separately, prevailing the effects of the addition present in a bigger proportion. The additions of limestone filler or fly ash - taken separately or altogether, determine a decrease of the setting time for the blended cements in comparison with Portland cement, the effect being stronger in the case of cements with greater addition of fly ash (20-30\%) [3]. The self compacting concretes with the limestone filler show higher water permeability and lower freeze - thaw resistance in the presence of de-icers than the concretes with the fly ash additive. These parameters can be improved by the higher fineness of limestone flour. The shortage of freeze - thaw resistance and the resistance to the attack of de-icers in case of the limestone containing self compacting concretes is the consequence of the microstructure of cement matrix [4].The use of limestone powder in cement and concrete provides economic and environmental advantages by reducing Portland cement production and $\mathrm{CO} 2$ emission, as well as improving the early and the later age compressive strength [5].In Konkan region of Maharashtra, the laterite stone is 
commonly used for the construction purpose. There are several laterite stone quarries in Konkan region. During excavation of laterite stone, around $25-30$ per cent laterite stone scrap is generated. It is estimated that about 2.83 cum of the laterite stone scrap is generated during excavation of about 11.33 cum of the laterite stone. This laterite stone scrap creates problem in quarries and needs removal for further excavation. In order to add value to this waste material, it is felt necessary to manufacture the blocks using different constituents that are suitable for the construction. In this In this overview determine the Compressive strength, toughness index and water absorption capacity of the laterite stone scrap blocks [6]. Laterite of relatively good quality for building purpose (high compressive strength and low water absorption) [7].In India, the conventional concrete is produced using natural sand from river beds as fine aggregate. Decreasing natural resources poses the environmental problem and hence government restriction on sand quarrying resulted in scarcity and significant increase in its cost. Normally particles are not present in river sand up to required quantity. Digging sand, from river bed in excess quantity is hazardous to environment. The deep pits dug in the river bed, affects the ground water level. In order to fulfill the requirement of fine aggregate, some alternative material must be found. The cheapest and the easiest way of getting substitute for natural sand is obtained from limestone quarries, lateritic sand and crushing natural stone quarries is known as manufactured sand. Laterite is a highly weathered material rich in secondary oxide of iron, aluminum or both. It is nearly devoid of base and primary silicates but may contain large amount of quarts, and kaolinite. Laterite has been used for well construction around the world. It is cheap, environmentally friendly and abundantly available building material in the tropical region. Concrete using various combinations of lateritic sand and quarry dust as complete replacement for conventional river sand. The result is found better workability and high compressive strength [8] Concrete is the most commonly used material for construction and their design consumes almost the total cement production in the world. The use of large quantities of cement produces increasing $\mathrm{CO}_{2}$ emissions, and as a consequence the green house effect. A method to reduce the cement content in concrete mixes is the use of silica fines. The ordinary Portland cement is partially replaced with silica fume and natural sand is replaced with manufactured sand by four proportions. The results indicated that there is an increase in the compressive and Flexural strength [9]. The ordinary Portland cement is partially replaced with nano-silica by $0.75 \%$ and natural sand is fully replaced with manufactured sand, the better compressive strength, flexural strength and better durability and corrosion resistance [10]. Concrete made with lateritic sand and lime stone filler as complete replacement for conventional river sand fine aggregate in concrete can attain more or less same compressive strength, tensile strength, permeability, modulus of rupture and lower degree of shrinkage as the control concrete. There are three different grades are used, namely: M15, M20 and M25. For both conventional sand and lateritic sand and lime stone filler. It is found that 0.55 water/cement ratio produced higher compressive strengths and better workability for M20 mix, proportion. Since we are replacing the proportion of $25 \%$ laterite to $75 \%$ lime stone filler produced higher values of compressive strength.

\section{AIM OF THE STUDY}

Fully replacement of lateritic sand and lime stone filler by natural sand. The study is mainly done to find the compression strength, corrosion resistance, tensile strength and economy in practice.

\section{3 .EXPERIMENTAL INVESTIGATION}

\subsection{Materials}

3.1.1 Cement: Portland pozzolanic cement 53 grade conforming to IS 8112 - 1989, and specific gravity of cement is found to be 3.15 .

3.1.2 Lateritic sand: Lateritic sand is partially replacement of river sand it is collected from BAG Groups Coimbatore, India. The bulk density of lateritic sand $1460 \mathrm{~kg} / \mathrm{m}^{2}$ and the specific gravity 2.56 and fineness modulus of rive Sand is 2.76. The properties of lateritic sand given in Table 1

Table - 1. Properties of lateritic sand

\begin{tabular}{|l|c|}
\hline \multicolumn{2}{|l|}{ Physical properties of Lateritic sand } \\
\hline Liquid limit & $28.76 \%$ \\
\hline Plastic limit & 13.4 \\
\hline Plasticity index & 14 \\
\hline Moisture content & $13.22 \%$ \\
\hline Sieve analysis & $0.53 \mathrm{~mm}$ to $4.2 \mathrm{~mm}$ \\
\hline
\end{tabular}

3.1.3 Lime stone filler: crushed limestone filler retained on the sieve No.300 is used with the specific gravity 2.64.The chemical compositions of lime stone filler given in table 2 and sieve analysis of limestone filler \& lateritic sand given in table 3

Table - 2. Chemical analysis of lime stone filler

\begin{tabular}{|l|l|}
\hline \multicolumn{1}{|c|}{ Component } & \multicolumn{1}{c|}{ Limestone powder } \\
\hline $\mathrm{SiO}_{2}$ & 1.81 \\
\hline $\mathrm{Fe}_{2} \mathrm{O}_{3}$ & 0.23 \\
\hline $\mathrm{Al}_{2} \mathrm{O}_{3}$ & 0.26 \\
\hline $\mathrm{CaO}$ & 52.38 \\
\hline $\mathrm{MgO}$ & 1.68 \\
\hline $\mathrm{SO}_{2}$ & 0.26 \\
\hline $\begin{array}{l}\mathrm{Blaine} \text { specific } \\
\text { surface }[\mathrm{m} 2 / \mathrm{kg}]\end{array}$ & 390 \\
\hline
\end{tabular}


Table - 3 .Sieve analysis of limestone filler \& lateritic sand

\begin{tabular}{|l|l|l|}
\hline $\begin{array}{c}\text { IS sieve } \\
\text { designation }\end{array}$ & $\begin{array}{c}\text { lateritic sand \% } \\
\text { Passing }\end{array}$ & $\begin{array}{l}\text { limestone filler \% } \\
\text { Passing }\end{array}$ \\
\hline $4.75 \mathrm{~mm}$ & 95.43 & 94.1 \\
\hline $2.36 \mathrm{~mm}$ & 92.84 & 90.23 \\
\hline $1.18 \mathrm{~mm}$ & 68.27 & 47.35 \\
\hline $600 \mathrm{~nm}$ & 49.27 & 34.6 \\
\hline $300 \mathrm{um}$ & 30 & 23 \\
\hline $150 \mathrm{um}$ & 9.27 & 5.3 \\
\hline
\end{tabular}

3.1.4 Fine aggregate: Locally available river sand having bulk density $1762 \mathrm{~kg} / \mathrm{m}^{3}$ is used and the specific gravity 2.73 and fineness modulus of river sand is 3.01

3.1.5 Course aggregate: Considering all the above aspects, blue granite crushed stone aggregate of $12 \mathrm{~mm}$ as maximum size and of typical particle shape "average and cubic" are used as the course aggregate for the present investigation. The aggregates are tested as per the procedure given in BIS: 2386- The bulk density of coarse aggregate $1690 \mathrm{~kg} / \mathrm{m} 2$ and the specific gravity 2.78 and fineness modulus of coarse aggregate 6.43

\section{EXPERIMENTAL PROCEDURE}

The mix ratio is prepared for $1: 2: 4,1: 1.5: 3$ and $1: 1: 2$, for both conventional and also lateritic and lime stone filler.The fine aggregate portion of the mix is achieved by combining lateritic and lime stone filler in ratio with $25 \%-75 \%, 50 \%$ $50 \%$ and $75 \%-25 \%$. The materials are then mixed thoroughly before adding the prescribed quantity of water and then mixed further to produced fresh concrete. Water cements ratios of 0.55 were adopted. The specimen is prepared for compressive strength for cube size $(150 \mathrm{x} 150 \mathrm{x}$ $150 \mathrm{~mm}$. The cylinder of height $30 \mathrm{~cm}$ and $15 \mathrm{~cm}$ diameter is prepared for tensile strength totally 108 cubes and 108 cylinders are made. The specimens are tested for 7 days, 14 days and 28 days with each proportion of conventional and lateritic and lime stone filler.

\section{RESULT AND DISCUSSION}

The Compressive and tensile strength of concrete are presented in table below

The test is carried out conforming to IS 516 -1959 to obtain compressive strength of concrete at the 7days, 14 days and 28 days. The cubes are tested using 400 tonne capacity HELICO compressive testing machine (CTM) .The results are presented in Fig. 1, 2, 3, and 4

\begin{tabular}{|c|c|c|c|c|}
\hline $\begin{array}{l}\text { Mix } \\
\text { ratio }\end{array}$ & $\begin{array}{c}\text { Conventional } \\
\text { concrete }\end{array}$ & $\begin{array}{c}25 \% \\
\text { LAT:75lime } \\
\text { stone filler }\end{array}$ & $\begin{array}{c}50 \% \\
\text { LAT } \\
: 50 \text { lime } \\
\text { stone } \\
\text { filler }\end{array}$ & $\begin{array}{c}75 \% \\
\text { LAT } \\
: 25 \text { lime } \\
\text { stone } \\
\text { filler }\end{array}$ \\
\hline M15 & 16.64 & 20.14 & 15.34 & 13.64 \\
\hline M20 & 22.12 & 26.72 & 20.42 & 18.72 \\
\hline M25 & 22.43 & 25.43 & 21.63 & 17.43 \\
\hline
\end{tabular}

The 7days compressive strength of conventional concrete, 50\%-50\% (Lat \& LSF)and 75\% - 25\%(Lat \& LSF) concrete $21.03 \%, 31.29 \%$ and $47.6 \%$ of compressive strength is reduced when compared to the $25 \%-75 \%$ ( Lat \& LSF) concrete which is found that $1: 2: 4$ mix ratio. The compressive strength of conventional concrete, 50\%-50\% (Lat \& LSF) and 75\% - $25 \%$ (Lat \& LSF) more or less same having M20 and M25grade of concrete. The Results of this test are show in table .4

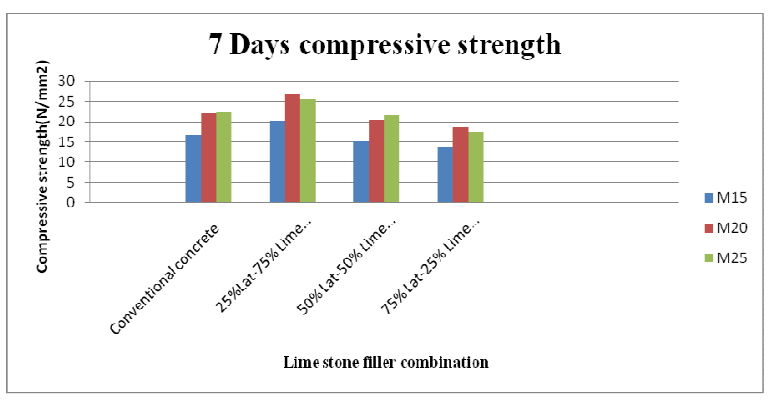

Figure:1 7 days compressive strength of concrete

Table -5. 14 Days compressive strength of concrete

\begin{tabular}{|c|c|c|c|c|}
\hline $\begin{array}{l}\text { Mix } \\
\text { ratio }\end{array}$ & $\begin{array}{c}\text { Conventional } \\
\text { concrete }\end{array}$ & $\begin{array}{c}25 \% \\
\text { LAT:75lime } \\
\text { stone filler }\end{array}$ & $\begin{array}{c}50 \% \\
\text { LAT } \\
\text { :50lime } \\
\text { stone } \\
\text { filler }\end{array}$ & $\begin{array}{c}75 \% \\
\text { LAT } \\
: 25 \text { lime } \\
\text { stone } \\
\text { filler }\end{array}$ \\
\hline M15 & 19.19 & 21.26 & 19.06 & 15.16 \\
\hline M20 & 27.12 & 30.12 & 26.72 & 20.12 \\
\hline M25 & 27.26 & 28.26 & 27.06 & 21.26 \\
\hline
\end{tabular}

The 14 days compressive strength of conventional concrete, $50 \%-50 \%$ (Lat \& LSF) and $75 \%-25 \%$ (Lat \& LSF) concrete $10.96 \%, 11.54 \%$ and $40.23 \%$ of compressive strength is reduced when compared to the $25 \%-75 \%$ ( Lat \& LSF) concrete which is found that 1:2:4 mix ratio. The compressive strength of conventional concrete, 50\%-50\% (Lat \& LSF) and 75\% - 25\% (Lat \& LSF) more or less same having M20 and M25 grade of cocrete. The Results of this test are show in table .5

Table -4. 7 Days Compressive of strength of concrete 


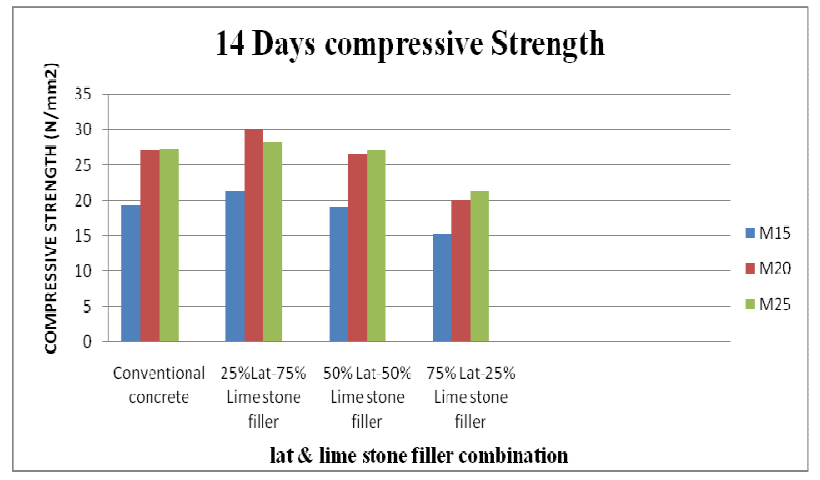

Figure:2 14 days compressive strength of concrete

Table -6. 28 Days compressive strength of concrete

\begin{tabular}{|c|c|c|c|c|}
\hline Mix & Conventional & $25 \%$ & $50 \%$ & $75 \%$ \\
& concrete & LAT:75lime & LAT & LAT \\
& & stone filler & $\begin{array}{c}\text { 50lime } \\
\text { stone } \\
\text { filler }\end{array}$ & $\begin{array}{c}\text { :25lime } \\
\text { stone } \\
\text { filler }\end{array}$ \\
& & & & \\
\hline M15 & 21.06 & 26.06 & 20.06 & 19.06 \\
\hline M20 & 33.12 & 36.12 & 35.12 & 23.12 \\
\hline M25 & 34.43 & 35.03 & 34.53 & 23.43 \\
\hline
\end{tabular}

The 28 days compressive strength of conventional concrete, $50 \%-50 \%$ (Lat \& LSF) and $75 \%$ - 25\% (Lat \& LSF) concrete $23.30 \%, 22.74 \%$ and $36.64 \%$ of compressive strength is reduced when compared to the $25 \%-75 \%$ ( Lat \& LSF) concrete which is found that 1:2:4 mix ratio. The compressive strength of conventional concrete, $50 \%-50 \%$ (Lat \& LSF) and 75\% - 25\% (Lat \& LSF) more or less same having M20 and M25 grade of concrete. The Results of this test are show in table 6

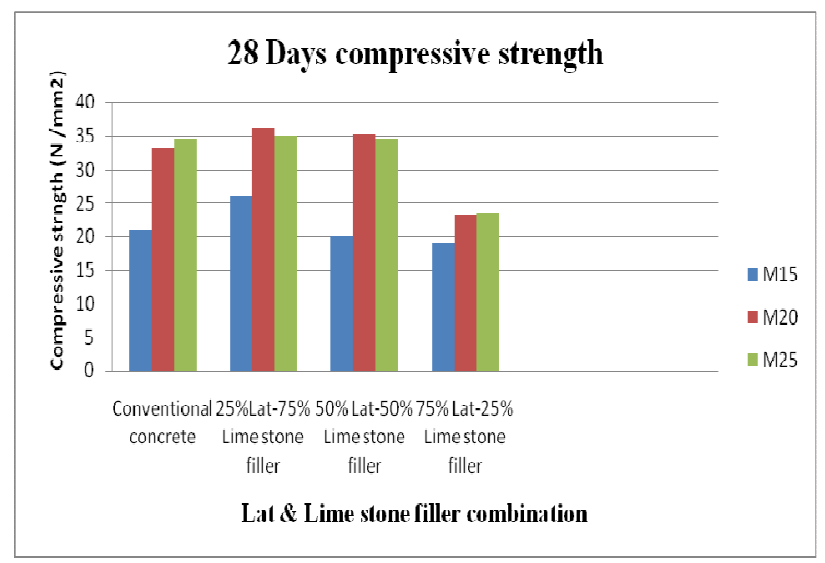

Figure:3 28 days compressive strength of concrete

Concrete made with lateritic sand and lime stone filler as complete replacement for conventional river sand fine aggregate in concrete can attain more compressive strength $25 \%$ LAT \& $75 \%$ Lime stone filler at M20 grade of concrete. The various combination of the compressive strength of concrete various mix ratios shown in figure .4

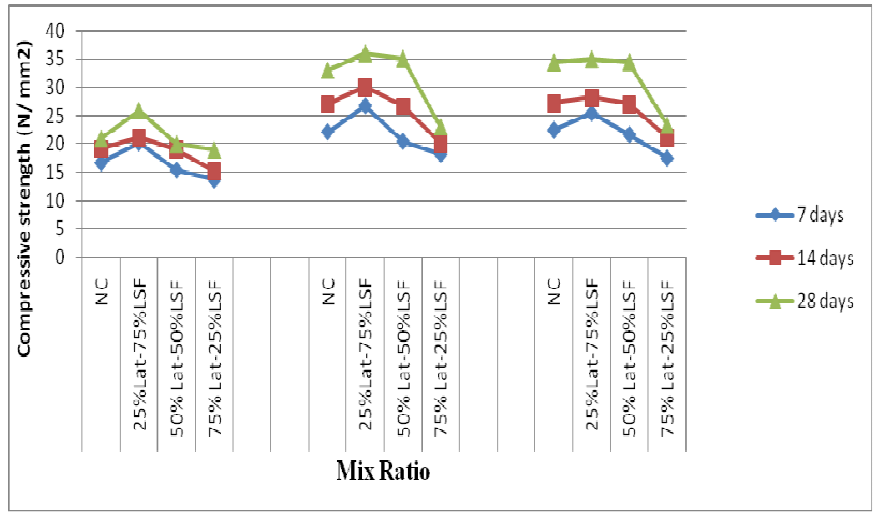

Figure:4. Compressive strength of concrete various mix ratio

The test is carried out conforming to IS 516-1959 to obtain tensile strength of concrete at the 7 days, 14 days and 28 days. The cylinders are tested using 400 tonne capacity HELICO compressive testing machine (CTM) .The results are presented in Fig.5,6 \& 7. Tensile strength of concrete are presented in table below

Table -7. 7 Days tensile strength of concrete

\begin{tabular}{|c|c|c|c|c|}
\hline $\begin{array}{l}\text { Mix } \\
\text { ratio }\end{array}$ & $\begin{array}{l}\text { Conventional } \\
\text { concrete }\end{array}$ & $\begin{array}{c}25 \% \\
\text { LAT:75lime } \\
\text { stone filler }\end{array}$ & $\begin{array}{c}50 \% \\
\text { LAT } \\
: 50 \text { lime } \\
\text { stone } \\
\text { filler }\end{array}$ & $\begin{array}{c}75 \% \\
\text { LAT } \\
: 25 \text { lime } \\
\text { stone } \\
\text { filler }\end{array}$ \\
\hline M15 & 2.35 & 2.46 & 2.24 & 2.02 \\
\hline M20 & 3.12 & 3.28 & 2.85 & 2.76 \\
\hline M25 & 3.14 & 3.26 & 2.8 & 2.69 \\
\hline
\end{tabular}

The 7days tensile strength of conventional concrete, 50\%$50 \%$ (Lat \& LSF) and 75\% - 25\% (Lat \& LSF) concrete $4.47 \%, 8.94 \% 17.88 \%$ of tensile strength is reduced when compared to the $25 \%-75 \%$ ( Lat \& LSF) concrete which is found that 1:2:4 mix ratio. The tensile strength of conventional concrete, $50 \%-50 \%$ (Lat \& LSF) and 75\% $25 \%$ (Lat \& LSF) more or less same having M20 and M25grade of concrete. The Results of this test are show in table 7

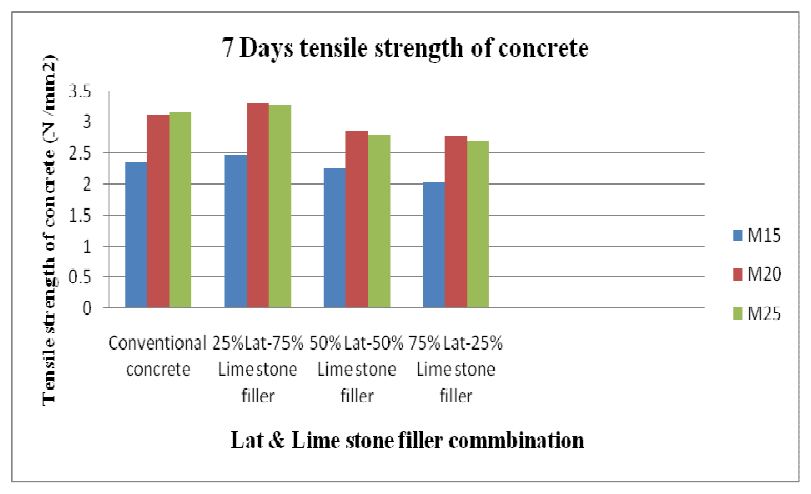

Figure:5 7 days tensile strength of concrete 
Table -8. 14 Days tensile strength of concrete

\begin{tabular}{|c|c|c|c|c|}
\hline $\begin{array}{l}\text { Mix } \\
\text { ratio }\end{array}$ & $\begin{array}{c}\text { Conventional } \\
\text { concrete }\end{array}$ & $\begin{array}{c}25 \% \\
\text { LAT:75lime } \\
\text { stone filler }\end{array}$ & $\begin{array}{c}50 \% \\
\text { LAT } \\
: 50 \text { lime } \\
\text { stone } \\
\text { filler }\end{array}$ & $\begin{array}{c}75 \% \\
\text { LAT } \\
: 25 \text { lime } \\
\text { stone } \\
\text { filler }\end{array}$ \\
\hline M15 & 2.46 & 2.62 & 2.22 & 2.12 \\
\hline M20 & 3.1 & 3.74 & 2.89 & 2.75 \\
\hline M25 & 3.12 & 3.28 & 2.78 & 2.69 \\
\hline
\end{tabular}

The 14 days tensile strength of conventional concrete, $50 \%$ $50 \%$ (Lat \& LSF)and 75\% - 25\%(Lat \& LSF) concrete 6.50 $\%, 18.01 \%$ and $23.54 \%$ of tensile strength is reduced when compared to the $25 \%-75 \%$ ( Lat \& LSF) concrete which is found that 1:2:4 mix ratio. The tensile strength of conventional concrete, $50 \%-50 \%$ (Lat \& LSF) and 75\% $25 \%$ (Lat \& LSF) more or less same having M20 and M25 grade of concrete. The Results of this test are show in table .8

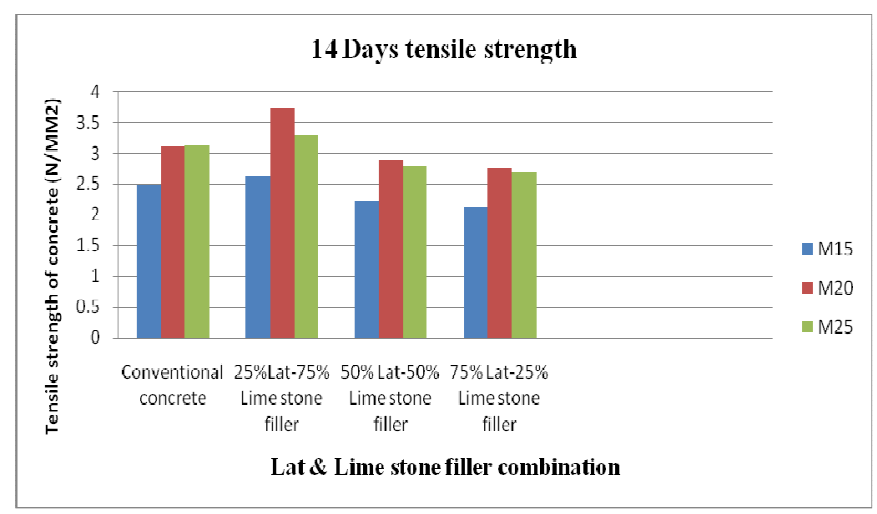

Figure:6 14 days tensile strength of concrete

Table -9. 28 Days tensile strength of concrete

\begin{tabular}{|c|c|c|c|c|}
\hline $\begin{array}{c}\text { Mix } \\
\text { ratio }\end{array}$ & $\begin{array}{c}\text { Conventional } \\
\text { concrete }\end{array}$ & $\begin{array}{c}25 \% \\
\text { LAT:75lime } \\
\text { stone filler }\end{array}$ & $\begin{array}{c}50 \% \\
\text { LAT } \\
\text { :50lime } \\
\text { stone } \\
\text { filler }\end{array}$ & $\begin{array}{c}75 \% \\
\text { LAT } \\
: 25 \text { lime } \\
\text { stone } \\
\text { filler }\end{array}$ \\
\hline M15 & 2.74 & 2.79 & 2.54 & 2.46 \\
\hline M20 & 3.46 & 3.52 & 3.41 & 2.92 \\
\hline M25 & 3.46 & 3.49 & 3.39 & 2.83 \\
\hline
\end{tabular}

The 28 days tensile strength of conventional concrete and $25 \%-75 \%$ ( Lat \& LSF) concrete is more or less same. The tensile strength of , 50\%-50\% (Lat \& LSF) and 75\% - 25\% (Lat \& LSF) concrete $9.84 \%$ and $11.38 \%$ of tensile strength is reduced when compared to the $25 \%-75 \%$ ( Lat \& LSF) concrete which is found that 1:2:4 mix ratio. The tensile strength of conventional concrete, $50 \%-50 \%$ (Lat \&
LSF) and 75\% - 25\% (Lat \& LSF) more or less same having M20 and M25 grade of concrete. The Results of this test are show in table .9

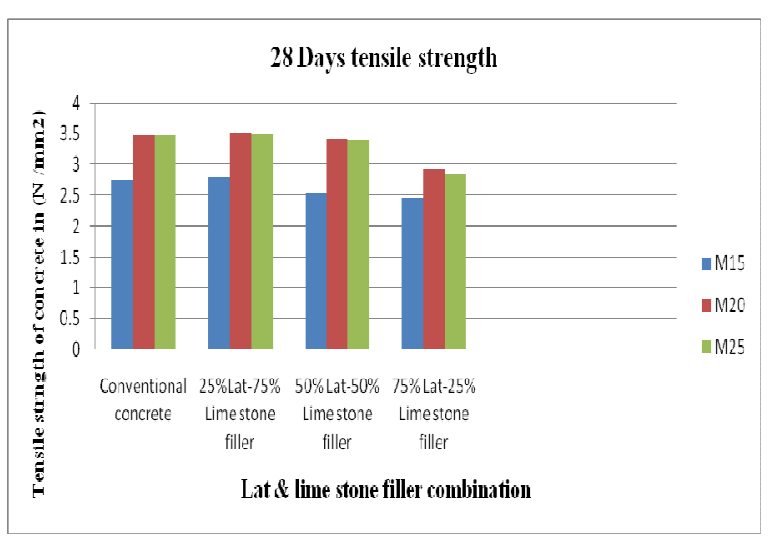

Figure:7 28 days tensile strength of concrete

\section{CONCLUSION}

It can be seen from the results of this study that the combination of laterite and lime stone filler replaces the conventional river sand in the production of concrete for construction industry.

The compressive strength and tensile strength of concrete using lateritic sand lime stone filler are measured in the laboratory. Compressive strength and tensile strength is found to increase with age as for normal concrete. The 28 - day compressive and tensile strength is found $21.06-35.2 \mathrm{~N} / \mathrm{mm}^{2}$ and 10.06 $-15.5 \mathrm{~N} / \mathrm{mm}^{2}$ for different mixes. The above strength properties the proportion of $25 \%$ laterite to $75 \%$ lime stone filler produced higher values of compressive strength. For the same proportion of $25 \%$ laterite to $75 \%$ lime stone filler at 1:15:3 mix and 0.55 water cement ratio, a logarithmic model has been developed for predicting the compressive strength and tensile of concrete between 0 and 28 days.

Further work is required to get data for other structural properties of the experimental concrete.

\section{REFERENCES}

[1]. Rana Burhan Abdurrahman Alshahway, (2011). "Effect of Partial Replacement of Sand with Limestone Filler on some properties of Normal Concrete."Al-Rafidain Engineering ,June 2011.Volume19 No.3

[2]. G. De Schutter, Ghent University, Belgium, (2011) "Effect of limestine filler as mineral addition in self-compacting concrete." 36th Conference on our world in concrete \& structures: 14 - 16 August 2011, Singapore 
[3]. Maria Georgescu, Nastasia Saca ,(2009)

"Properties of blended cements with limestone filler and fly ash content". U.P.B. Sci. Bull., Series B, Vol. 71, Iss. 3, 2009 ISSN 1454-2331

[4]. Stefania Grzeszczyk ,Piotr Podkowa,(2009) "The Effect of Limestone Filler on the Properties of Self Compacting Concrete". Annual transactions of the nordic rheology society, vol. 17, 2009

[5]. By Tarun R. Naik, Fethullah Canpolat, Yoonmoon Chun ,(2003) "Limestone powder use in cement and concrete". Department of Civil Engineering and Mechanics College of Engineering and Applied Science the university of wisconsin Milwaukee.

[6]. S.K. Jai1, P.G. Patil, N.J. Thakor,(2011) "Engineering properties of laterite stone scrap blocks".Agricultural Engineering International: CIGR Journal. Vol.13, No.3, 2011. ManuscripNo.1738.

[7]. Kasthurba. A. K, (2012) "Characteristics of Malabar Laterite as a Building Material Field and Laboratory Studies". International journal of earth secience. ISSN 0974-5904, Volume 05, No. 03 (01)

[8]. Joseph O. Ukpata, Maurice E.Ephraim and GodwinA. Akeke.(2012). "Compressive strength of Concrete using Lateritic Sand and Quarry Dust as Fine Aggregate.”Arpn Journal of Engineering and Applied Sciences, Junuary 2012.Volume 7,No.1.

[9]. T.Shanmugapriya, R.N.Uma,(2012).“Optimation of Partial Replacement of M-Sand by Natural sand in High Performance Concrete With Silica Fume." International Jouranal of Engineering Sciences \& Emerging Technologies, June 2012.Volume 2, pp:73.-80 IJESET

[10].A.Jayaraman ， V.Senthil kumar,(2013). "Optimization of fully replacement of natural sand by M-sand in high performance concrete with nanosilica". International Journal of Emerging Technology and Advanced Engineering., Volume 3, Issue 11, November 2013) 